\title{
Penghentian Konsumsi Alkohol Pada Remaja Dengan Langkah Menerapkan Germas
}

\author{
Laurent Nadia Asmoro Putri \\ Institut Ilmu Kesehatan Strada Indonesia \\ laurentnadia154@gmail.com
}

\begin{abstract}
Abstrak
$\underline{\text { GERMAS }}$ adalah sebuah gerakan yang bertujuan untuk memasyarakatkan budaya hidup sehat serta meninggalkan kebiasaan dan perilaku masyarakat yang kurang sehat. Aksi GERMAS ini juga diikuti dengan memasyarakatkan perilaku hidup bersih sehat dan dukungan untuk program infrastruktur dengan basis masyarakat.Perilaku konsumsi alkohol kini sudah menjadi kebiasaan semua komunitas baik di dunia maupun di Indonesia, tidak heran apabila alkohol kini mulai merambah ke generasi muda, terutama remaja. Rasa ingin mencoba hal baru yang dimiliki remaja kini mendorong remaja untuk mengkonsumsi alkohol. Tentu saja hal ini dapat merusak mental maupun psikis dari remaja itu sendiri. Penyalahgunaan minuman keras saat ini merupakan permasalahan yang cukup berkembang di dunia remaja dengan prevalensi yang sangat tinggi. sebesar $61,7 \%$ dari penduduk berusia 15 tahun atau lebih tua (15+) di seluruh dunia pernah minum alkohol dalam 12 bulan terakhir, bahkan sekitar 16,0\% adalah peminum berat.
\end{abstract}

\section{Kata kunci : Germas,Perilaku konsumsi alkohol, Remaja}

\section{Latar Belakang}

GERMAS adalah sebuah gerakan yang bertujuan untuk memasyarakatkan budaya hidup sehat serta meninggalkan kebiasaan dan perilaku masyarakat yang kurang sehat. Aksi GERMAS ini juga diikuti dengan memasyarakatkan perilaku hidup bersih sehat dan dukungan untuk program infrastruktur dengan basis masyarakat.

Remaja didefinisikan sebagai masa peralihan dari kanak-kanak ke masa dewasa, dan batasan umur remaja menurut World Health Organization (WHO, 2007) adalah 12 sampai 24 tahun. Jika pada usia remaja seorang sudah menikah, tidak lagi tergolong sebagai remaja. Remaja merupakan masa transisi masa kanak-kanak menuju dewasa,dimana pada masa remaja 
tidak hanya perubahan bentuk tubuhnya, tetapi juga serangkaian perkembangan yang kompleks dan saling terkait.

Alkoholisme adalah orang yang kecanduan minum-minuman keras yang mengandung alkohol dalam dosis yang tinggi. Konsumsi alkohol, dapat menimbulkan dampak yang sangat merusak bagi individu pemakai maupun bagi masyarakat. Dalam alkohol terdapat racun protopasmik yang mempunyai akibat pada sitem syaraf. Dikalangan pelajar, angka tertinggi pengonsumsi alkohol dan tembakau berada di Eropa. Di Amerika dan Afrika pada periode tertinggi risiko untuk mulai minum alkohol yaitu usia 14-16 tahun.

Lingkungan pergaulan sangatlah berpengaruh tesrhadap remaja khususnya dalam tindakan konsumsi minuman beralkohol. Perilaku konsumsi minuman beralkohol dikalangan remaja biasanya dipengaruhi oleh lingkungan sekitar dan teman sebayanya, dan ketersediaan minuman beralkohol di masyarakat yang begitu muda didapat merupakan salah satu faktor penyebab penyalagunaan konsumsi alkohol dikalangan remaja. Dari minum-minuman beralkohol tersebut biasanya terjadi tindakan kirimnal karena pengaruh minuman beralkohol. Selain terjadi tindakan kriminal Minuman beralkohol juga dapat menyebabkan berbagai penyakit, ada penelitian yang dilakukan konsumsi alkohol pada jangka panjangakan menyebakan gangguan fungsi hati.

Sikap peduli kesehatan merupakan pola hidup sehat ,sikap peduli kesehatan dapat diterapkan mulai dari keluarga seperti tidak mengkonsumsi minuman keras .banyak program yang dilandaskan tentang pentingnya peduli kesehatan karena dapat dijadikan acuan melakukan germas.

Konsumsi minuman keras merupakan kebiasaan yang banyak memberi dampak buruk bagi kesehatan.Berhenti mengkonsumsi minuman beralkohol menjadi bagian penting dari gerakan dan akan berdampak baik bagi diri seorang pengkonsumsi minuman beralkohol,tetapi juga berdampak pada lingkungan maupun orang disekitarnya.

\section{Kasus/Masalah}

Dari uraian latar belakang diatas dapat dirumuskan masalah sebagai berikut : Bagaimana cara menghentikan konsumsi minuman beralkohol pada remaja dengan menerapakan Germas. 


\section{Tinjauan Pustaka}

\subsection{Definisi GERMAS}

GERMAS adalah sebuah gerakan yang bertujuan untuk memasyarakatkan budaya hidup sehat serta meninggalkan kebiasaan dan perilaku masyarakat yang kurang sehat. Aksi GERMAS ini juga diikuti dengan memasyarakatkan perilaku hidup bersih sehat dan dukungan untuk program infrastruktur dengan basis masyarakat.

\subsection{Definisi Alkoholisme}

Alkoholisme adalah orang yang kecanduan minum-minuman keras yang mengandung alkohol dalam dosis yang tinggi. Konsumsi alkohol, dapat menimbulkan dampak yang sangat merusak bagi individu pemakai maupun bagi masyarakat. Dalam alkohol terdapatracun protopasmik yang mempunyai akibat pada sitem syaraf. Di kalangan pelajar, angka tertinggi pengonsumsi alkohol dan tembakau berada di Eropa. Di Amerika dan Afrika pada periode tertinggi risiko untuk mulai minum alkohol yaitu usia 14-16 tahun(Donovan, 2004).

\subsection{Definisi Konsonsumsi minuman beralkohol}

Lingkungan pergaulan sangatlah berpengaruh tesrhadap remaja khususnya dalam tindakan konsumsi minuman beralkohol. Perilaku konsumsi minuman beralkohol dikalangan remaja biasanya dipengaruhi oleh lingkungan sekitar dan teman sebayanya, dan ketersediaan minuman beralkohol di masyarakat yang begitu muda didapat merupakan salah satu faktor penyebab penyalagunaan konsumsi alkohol dikalangan remaja. Dari minumminuman beralkohol tersebut biasanya terjadi tindakan kirimnal karena pengaruh minuman beralkohol. Selain terjadi tindakan kriminal Minuman beralkohol juga dapat menyebabkan berbagai penyakit, ada penelitian yang dilakukan konsumsi alkohol pada jangka panjangakan menyebakan gangguan fungsi hati.(Conreng,2017)

\section{Pembahasan}

\subsection{Konsumsi minuman beralkohol pada kalangan remaja}

Alkoholisme adalah orang yang kecanduan minum-minuman keras yang mengandung alkohol dalam dosis yang tinggi. Konsumsi alkohol, dapat menimbulkan dampak yang sangat merusak bagi individu pemakai maupun bagi masyarakat.

Minuman keras merupakan minuman yang mengandung zat adiktif (alkohol) dan dapat menyebabkan kesadaran, mempengaruhi perilaku, cara berpikir sehingga orang menjadi tidak normal. Konsumsi minuman keras di Indonesia meningkat seiring perkembangan informasi dan layanan transportasi. Kemudahan akses untuk mendapatkan minuman keras juga menjadi faktor peningkatan konsumsi minuman keras. 
Kesehatan Reproduksi Remaja, menyebutkan bahwa prevalensi remaja (usia 15-24 tahun) yang minum-minuman beralkohol berada pada dua kategori yaitu minum setiap hari dan hanya kadang-kadang, dengan presentase pria yang minum-minuman beralkohol lebih besar daripada wanita yaitu $15 \%$ dan $1 \%$. Sekitar $70 \%$ pria dan $58 \%$ wanita mulai minum alkohol pada rentang usia 15-19 tahun.

Sebagian besar remaja yang mengonsumsi minuman beralkohol mengatakan bahwa kepercayaan diri mereka bertambah dari yang pemalu menjadi pemberani, mereka beranggapan bahwa semua masalah dapat teratasi dengan meminum minuman beralkohol, tapi meminumminuman beralkohol dapat merusak proses berpikir dan menjdikan seseorang tidak sadarkan diri atau bertindak tidak sesuai kehendaknya.

Dampak mengkonsumsi minuman beralkohol dapat menyebabkan gangguan pada tubuh seperti kerusakan hati dan penkreas, diabetes, obesitas,depresi. kesehatan fisik remaja akibat dari mengkonsumsi minuman beralkohol terlihat dari tubuh remaja yang kurus, mata cekung dan merah, bibir hitam,berjalan sempoyongan, bahkan hingga muntah dan tidak bisa bangun.Adapun dampak bagi kesehatan jiwa remaja cenderung banyak bicara yang aneh dan jorok,mudah tersinggung dan marah, moodnya berubah-ubah, merokok terus, tidak pernah konsentrasi, dan sering mengusap dan memegang kepala.Tidak hanya itu,mengkonsumsi minuman beralkohol pada remaja juga berakibat pada keamanan dan ketertiban masyarakat, yaitu ribut hingga larut malam, menghidupkan musik keras-keras, teriakteriak sambil bernyanyi, mencuri dan menyebabkan perkelahian.

\subsection{Faktor penyebab konsumsi minuman keras pada remaja}

faktor-faktor tambahan yang memengaruhi kebiasaan konsumsi minuman keras pada remaja:

\section{Keluarga}

Kemungkinan besar bukan faktor rasa yang memicu keinginan remaja lebih banyak minum minol, melainkan mereka tumbuh dalam lingkungan dimana alkohol secara teratur disediakan orang tua mereka dalam pergaulan sosial mereka.

\section{Teman sebaya}

Jika anak Anda berteman dengan teman sebaya yang memberikan pengaruh positif, maka mereka akan jauh dari sentuhan minol. Sebaliknya, jika mereka memiliki teman sebaya dengan kebiasaan yang suka minum minol, maka anak Anda sangat mungkin akan mengikutinya juga.

\section{Budaya}

Kemudahan remaja untuk mendapatkan mikol turut berkontribusi mendorong pola konsumsi minuman keras mereka semakin tinggi. Pendidikan orang tua adalah kunci dalam mencegah penyalahgunaan atau ketergantungan anaknya pada minol.Misalnya, seorang remaja Indonesia yang kuliah di luar negeri mungkin akan terpengaruh untuk mencoba minol karena masingmasing negara memiliki hukum berbeda menyikapi penggunaan alkohol. 


\section{Media}

Studi dari Journal of Pediatrics menemukan ketika remaja sering menonton adegan penggunaan minol dalam film, maka itu juga memengaruhi faktor apakah mereka mau atau tidak mencoba hal yang sama.

\section{Teknologi}

Anak-anak menggunakan media sosial untuk menemukan hal-hal yang tidak mereka ketahui. Mereka juga menyadari mabuk bisa membuat mereka melakukan hal-hal bodoh. Namun, berkat teknologi juga anak bisa terpapar alkohol. Teknologi memiliki pengaruh yang besar juga.

\subsection{Efek Pemberhentian Konsumsi Minuman Keras}

memiliki kebiasaan minum bahkan hingga sudah pada tahap kecanduan, terkadang memang sulit untuk mulai berhenti minum alkohol. Dalam sebuah studi, alkohol menjadi faktor risiko utama berbagai penyakit dan kematian dini pada pria serta wanita usia 15-49 tahun di seluruh dunia pada tahun 2016. Menurut penelitian tersebut, hampir 1 dari 10 kematian disebabkan oleh alkohol. Pada tahun tersebut, kematian yang disebabkan oleh alkohol tercatat ada 2,8 juta kasus.Dari penjelasan tersebut,jika remaja berusaha untuk menghentikan mengkonsumsi minuman keras akan terjadi perubahan pada dirinya seperti mood pada dirinya menjadi tidak dapat terkontrol,maka perlu dukungan dari sekitar atau orang terdekat sehingga mood dapat terkontrol dengan baik.Hambatan bagi remaja yang ingin berhenti mengkonsumsi minuman keras adalah masih banyak ditemui lingkungan terdekatnya yang mengkonsumsi minuman beralkohol,maka kesadaran dari dalam diri untuk menjaga kesehatan sangat penting dan dukungan orang terdekat.

\subsection{Sosialisasi Germas Kepada Kalangan Remaja}

Dengan melihat fakta dan data yang ada dapat memberikan fakta bawasannya bahwa dengan berkembangnya teknologi dapat mengedukasi kalangan remaja terkait bahaya mengkonsumsi minuman keras.Hal ini dapat menjadi trobosan kita dengan memanfaatkan program GERMAS dengan tujuan agar kalangan remaja menjauhi pengkonsumsian minuman beralkohol sehingga dapat tercapai tujuan pola dan perilaku hidup sehat dikalangan remaja saat ini.

Metode yang dapat digunakan diantaranya dengan promosi kesehatan dengan menggunakan social media dan sosialisasi di sekolah maupun lingkungan sekitar dengan materi yang menarik.

\subsection{Opini Penulis}

Pada kalangan remaja sangat banyak ditemui kasus mengkonsumsi minuman beralkohol hal ini menjadi tantangan kita untuk menerapkan Gerakan Masyrakat Hidup Bersih dan Sehat (GERMAS) sehingga tercipta masyarakat yang peduli akan kesehatan.Oleh karena itu kita perlu melakukan inovasi dan trobosan yang menarik agar pemyampaian edukasi bisa diterapkan oleh remaja saat ini. 


\section{Kesimpulan}

Bagi para remaja sebisa mungkin harusmengurangi jumlah konsumsi minuman keras karena dapat menimbulkan masalahkesehatan. Bagi para orang tua harus bisa meningkatkan tingkat pengawasankepada anak supaya tidak mengkonsumsi minuman keras, tetuta pola asuh anak karena faktor tersebut sangat berpengaruh dengan tingkat perkembangan anak.Pemberian edukasi terkait larangan mengkonsumsi minuman beralkohol melalui program GERMAS akan sangat membantu dalam mengurangi angka kecanduan minuman beralkohol pada remaja dan angka kematian akibat pengkonsumsian minuman beralkohol.

\section{Daftar Pustaka}

Badan penelitian dan pengembangan departemen kesehatan, 2013.Laporan 2007 riset Kesehatan Dasar (RIKESDAS) 2007 Republik Indonesia

Conreng, 2014. Hubungan konsumsi alcohol dengan gangguan fungsi hati pada subjek pria dewasa muda dikelurahan teteli dan teling atas manado. Manado s: Fakultas Kedokteran Universitas Sam Ratulagi. Jurnal e-CliniC (eCl, vol.2 no.2. Diakses online pada tanggal 25 agustus 2017

Donovan J. 2004. Adolescent Alchol Initition ; A Review of Psychosocial Rick Factors.Journal of Adolescent health.Journal of adolescent health,33;529, e7-529. e18. (Diakses online pada tanggal 8 Maret 2017)

Sarwono 2016. Psikologi Remaja. Jakarta; Rajawali Pers Pratama 2013. Perilaku Remaja Pengguna Minuman Keras di Desa Jatigono Kecamatan Kunir Kabupaten Lumajang. Faklutas Kesehatan Masyarakat Universitas Airlangga.

https://promkes.kemkes.go.id/germas

https://www.republika.co.id/berita/nasional/umum/15/04/17/nmxpzc-ini-penyebab-remajaketagihan-minuman-beralkohol 